\title{
KUALITAS AUDIT: FAKTOR AUDITOR DAN AUDITEE
}

\begin{abstract}
Financial statements provide accounting information that can be used by users for decision making. To avoid material misstatement, financial statements need to be audited by qualified independent auditors. The auditor is expected to be able to provide guarantees through opinions given to the company's accounting information. This study aims to determine the effect of auditor factors (audit tenure, audit fees, auditor market share) and auditee factors (company size and publication age) on audit quality. The object of research is nonfinancial state-owned companies listed on the Indonesia Stock Exchange in 2014-2018. With the purposive sampling method obtained 16 company samples or 77 observational data after subtracting three outlier data. The data were analyzed by logistic regression analysis.The results showed that the auditor factors and the auditee factors had a simultaneous effect on audit quality. Meanwhile, partially only the auditor factors affect audit quality, namely; audit tenure had a positive effect and auditor's market share had a negative effect on audit quality. The novelty of this study is market capitalization as a proxy for firm size variables with the main issue of audit quality. It is recommended for further research to re-examine variables that do not support the research hypothesis on the research object and different observation periods. For the auditor, it is advisable to consider the auditor's workload, because it is feared that it will cause the auditor's dysfunctional behavior which can result in an inferior audit.
\end{abstract}

ABSTRAK: Laporan keuangan menyediakan informasi akuntansi yang dapat dimanfaatkan oleh penggunanya untuk pengambilan keputusan. Agar terhindar dari salah saji material, laporan keuangan perlu diaudit oleh auditor independen yang berkualitas. Auditor diharapkan mampu memberikan jaminan melalui opini yang diberikan terhadap informasi akuntansi perusahaan. Penelitian ini bertujuan untuk mengetahui pengaruh faktor auditor (audit tenure, audit fee, pangsa pasar auditor) dan faktor auditee (ukuran perusahaan dan umur publikasi) terhadap kualitas audit. Objek penelitian adalah perusahaan BUMN nonkeuangan yang terdaftar di Bursa Efek Indonesia tahun 20142018. Dengan metode purposive sampling diperoleh 16 sampel perusahaan atau 77 data observasi setelah dikurangi tiga data oulier. Data tersebut dianalisis dengan analisis regresi logistik. Hasil penelitian menunjukkan bahwa faktor auditor (audit tenure, audit fee \& pangsa pasar auditor) dan faktor auditee (ukuran perusahaan \& umur publikasi) berpengaruh simultan terhadap kualitas audit. Sementara itu, secara parsial yang berpengaruh hanya faktor auditor, yaitu; audit tenure berpengaruh postif dan pangsa pasar auditor berpengaruh negatif tehadap kualitas audit. Kebaruan penelitian ini adalah menggunakan proksi kapitalisasi pasar untuk variabel ukuran perusahaan dengan isu utama kualitas audit.

\author{
Maya Nur Izzati Diny ${ }^{1}$, Majidah ${ }^{2}$ \\ ${ }^{1,2}$ Akuntansi, Fakultas Ekonomi \\ dan Bisnis, Telkom University \\ Bandung, Indonesia
}

Keywords: Quality of Audit, Auditor Factor, Auditee Factor

Kata Kunci:

Kualitas Audit, Faktor

Auditor, Faktor Auditee 


\section{Pendahuluan}

Laporan keuangan menyediakan informasi akuntansi yang dapat dimanfaatkan oleh penggunanya untuk pengambilan keputusan. Agar terhindar dari salah saji material yang dapat menyesatkan penggunanya, laporan keuangan perlu diaudit oleh auditor independen yang berkuliatas. Dengan demikian, auditor diharapkan mampu memberikan jaminan melalui opini yang diberikan terhadap informasi akuntansi.

Indikator kualitas audit yang harus dimiliki oleh auditor, salah satunya adalah kompetensi auditor (IAPI, 2018). Kompetensi tersebut dapat diperoleh auditor melalui latar belakang pendidikan dan pengalaman yang memadai, sehingga auditor mampu mendeteksi adanya salah saji material ataupun peluang terjadinya praktik kecurangan yang dilakukan oleh manajemen. Pendeteksian kecurangan untuk menilai kualitas audit antara lain dapat dilakukan dengan menggunakan pendekatan earnings surprise benchmark.

Auditor yang tidak mampu mendeteksi adanya praktik kecurangan yang dilakukan oleh perusahaan mengindikasikan hasil audit yang tidak berkualitas. Permasalahan ini terjadi pada kasus Akuntan Publik KS yang merupakan partner BDO Indonesia dalam mengaudit laporan keuangan PT GIAA tahun 2018. Kasus ini terkait dengan kejanggalan transaksi kerja sama antara PT GIAA dan PT MAT serta adanya rekayasa keuangan. Dalam laporan keuangan tersebut, tertulis bahwa perusahaan memperoleh laba, padahal setelah dilakukan pemeriksaan, diketahui PT GIAA merugi dalam jumlah besar di tahun 2018. Namun demikian, auditor justru memberikan Opini Wajar Tanpa Pengecualian (WTP) yang mengindikasikan ketidakmampuan auditor dalam mendeteksi kecurangan yang dilakukan oleh PT GIAA. Hal tersebut terindikasi akibat keterbatasan auditor dalam mendapatkan bukti, sehingga melanggar Standar Audit 500 tentang Bukti Audit (IAPI, 2012). Atas pelanggaran tersebut, Menteri Keuangan dan OJK memberikan sanksi kepada Akuntan Publik KS berupa pembekuan izin selama 12 bulan (www.katadata.co.id).

Fenomena lain terjadi di perusahaan BUMN non-keuangan yang terindikasi audit tidak berkualitas yang diukur menggunakan pendekatan earnings surprise benchmark, sebagaimana tabel berikut:

\begin{tabular}{|c|c|c|c|}
\hline Tahun & $\begin{array}{c}\text { Indikasi } \\
\text { window } \\
\text { dressing }\end{array}$ & $\begin{array}{c}\text { Indikasi taking } \boldsymbol{a} \\
\text { bath }\end{array}$ & Jumlah \\
\hline 2014 & 5 & 3 & 8 \\
\hline 2015 & 4 & 2 & 6 \\
\hline 2016 & 2 & 1 & 3 \\
\hline 2017 & 2 & 3 & 5 \\
\hline 2018 & 2 & 1 & 3 \\
\hline Jumlah & $\mathbf{1 5}$ & $\mathbf{1 0}$ & $\mathbf{2 5}$ \\
\hline
\end{tabular}

Sumber: data diolah dari Laporan Keuangan Audited 2014-2018.

Berdasarkan Tabel 1, terdapat 15 perusahaan BUMN non-keuangan selama tahun 2014-2018 yang terindikasi auditornya tidak mampu mendeteksi adanya window dressing atau manajemen memanipulasi laba agar kinerja laporan terlihat baik. Sementara itu, sebanyak 10 perusahaan yang terindikasi auditornya tidak mampu mendeteksi taking a bath atau manajemen membuat laporan terlihat buruk. Jumlah tersebut menunjukkan $31,25 \%$ dari total keseluruhan perusahaan BUMN non-keuangan selama 20142018. Jika tidak diidentifikasi faktor-faktor penyebabnya, maka kondisi ini akan terus bertambah dan menyebabkan kerugian material bagi pengguna laporan keuangan dalam mengambil keputusan maupun bagi reputasi perusahaan.

Beberapa penelitian terdahulu terkait dengan kualitas audit dan faktor yang mempengaruhinya, baik dari sisi auditor ataupun auditee dapat dijelaskan sebagai berikut.

Audit tenure atau masa perikatan auditor merupakan salah satu faktor yang dapat mempengaruhi kualitas audit. Jika audit tenure melebihi regulasi, yaitu regulasi lama adalah 3 
tahun dan regulasi yang baru selama 5 tahun, maka dapat mengganggu independensi auditor, sehingga dapat menurunkan kualitas audit. Hal tersebut sejalan dengan penelitian Pramaswaradana \& Astika (2017) dan Paramita \& Latrini (2015) yang menyatakan bahwa audit tenure berpengaruh negatif terhadap kualitas audit. Berbeda dengan hasil penelitian yang mengatakan audit tenure tidak mempengaruhi kualitas audit (Diana MD \& Majidah; 2019). Penelitian lain menunjukkan bahwa semakin lama audit tenure, justru dapat meningkatkan kualitas audit (Alareeni, 2019).

Audit fee juga merupakan faktor penentu kualitas audit. Audit fee merupakan biaya yang dibayarkan oleh klien kepada auditornya atas jasa audit yang diberikan. Hasil penelitian menujukkan bahwa Audit fee berpengaruh positif terhadap kualitas Audit (Abdul-Rahman et al., 2017; Ndubuisi \& Ezechukwu, 2017). Hal ini menunjukkan bahwa biaya audit yang tinggi dapat memotivasi auditor untuk menghasilkan audit yang berkualitas. Hasil ini bertolak belakang dengan hasil penelitian Pham, Duong, \& Quang (2017) bahwa audit fee berpengaruh negatif terhadap kualitas audit dan juga tidak sejalan dengan penelitian yang dilakukan Alfariza et al. (2017) yang menujukkan audit fee tidak memiliki pengaruh terhadap kualitas audit.

Pangsa pasar auditor merupakan istilah yang menunjukkan pada sebutan spesialisasi auditor (Alfariza et al., 2017:2571). KAP yang memiliki pangsa pasar yang besar dalam suatu industri dapat dikatakan sebagai auditor spesialis, karena dianggap memiliki kompetensi dan keahlian pada industri tersebut. Spesialis auditor industri dianggap mampu memberikan hasil audit yang berkualitas. Menurut penelitian Udayanti \& Ariyanto (2017) dan Alareeni (2019) spesialisasi industri KAP berpengaruh positif terhadap kualitas audit, sedangkan penelitian Alfariza, Majidah, \& Nurbaiti (2017) menyatakan pangsa pasar auditor atau spesialisasi auditor berpengaruh negatif terhadap kualitas audit dan penelitian Pramaswaradana \& Astika (2017) menyatakan spesialisasi auditor tidak memberikan pengaruh terhadap kualitas audit.

Perusahaan yang besar cenderung lebih memiliki informasi yang lebih banyak dan pengawasan yang lebih kuat dibandingkan perusahaan yang lebih kecil (Berikang et al., 2018). Perusahaan yang besar juga dianggap memiliki sistem pengendalian internal yang lebih baik dibandingkan perusahaan kecil, sehingga dapat membantu auditor untuk menghasilkan audit yang berkualitas. Hasil penelitian menunjukkan bahwa ukuran perusahaan berpengaruh positif terhadap kualitas audit (Berikang et al., 2018 dan Gacar; 2016). Penelitian lain menunjukkan berbeda; ukuran perusahaan tidak mempengaruhi kualitas audit (Paramita \& Latrini; 2015), Tetapi hasil penelitian lain menunjukkan ukuran perusahaan justru berpengaruh negatif terhadap kualitas audit (Udayanti \& Ariyanto, 2017).

Faktor auditee yang lain adalah umur publikasi juga dapat mempengaruhi kualitas audit. Umur publikasi merupakan lamanya perusahaan publik listing di pasar modal. Hasil penelitian menunjukkan bahwa perusahaan yang lebih muda cenderung memiliki sumber daya yang terbatas dan kemampuan yang kurang dalam membayar auditor spesialis, sehingga tidak mampu mengarahkan hasil audit yang berkualitas (Diana MD \& Majidah, 2019; Gacar, 2016). Sedangkan penelitian lain menunjukkan bahwa umur perusahaan tidak mampu mempengaruhi kualitas audit (Pramaswaradana \& Astika, 2017; Paramita \& Latrini, 2015).

Hasil penelitian tentang kualitas audit dan faktor yang mempengaruhinya, masih inkonsisten, oleh karena itu peneliti termotivasi untuk meniliti kualitas audit dan faktor yang mempengaruhinya di BUMN non-keuangan yang listing di Bursa Efek Indonesia pada tahun 2014-2018.

\section{Pengembangan Hipotesis}

Pengembangan hipotesis mengacu pada hasil penelitian terdahulu tentang faktor auditor 
dan faktor auditee yang mempengaruhi kualitas audit, sebagai berikut:

\subsection{Faktor Auditor dan Kualitas Audit}

Audit tenure atau masa perikatan audit yang terlalu lama dapat mengancam independensi serta objektivitas auditor dalam melakukan proses audit. Hasil penelitian menunjukkan bahwa audit tenure berpengaruh negatif terhadap kualitas audit (Pramaswaradana \& Astika, 2017). Hal tersebut terjadi karena perikatan audit yang lama dapat mengancam independensi auditor, sehingga auditor tidak berani untuk mengungkapkan kejadian sebenarnya. Hasil penelitian yang sama juga dijumpai pada penelitian Paramita \& Latrini (2015) yang menyatakan bahwa audit tenure berpengaruh negatif terhadap kualitas audit.

H1: Audit tenure berpengaruh negatif terhadap kualitas Audit

Audit fee merupakan imbalan jasa yang diberikan oleh perusahaan kepada auditor atas jasa yang telah hasilkan. Dalam menetapkan besaran audit fee, auditor harus cermat mempertimbangkan ruang lingkup penugasan, masa audit, dan jumlah tim, sehingga auditor dapat memberikan kualitas yang baik. Semakin besar audit fee yang diterima oleh auditor, maka auditor akan lebih termotivasi untuk memberikan hasil audit yang maksimal. Dengan begitu, kualitas audit yang dihasikan pun meningkat. Pernyataan tersebut didukung dengan hasil penelitian Pramaswaradana \& Astika (2017), Abdul-Rahman et al. (2017), dan Ndubuisi \& Ezechukwu (2017) menunjukkan audit fee berpengaruh positif terhadap kualitas audit.

$\mathrm{H} 2$ : Audit fee berpengaruh positif terhadap kualitas audit

Pangsa pasar auditor merupakan ukuran dari seberapa mampu KAP menguasai pasar atau suatu kelompok perusahaan. KAP yang menguasai pasar atau dapat disebut dengan KAP spesialis diyakini memiliki kompetensi yang bagus dalam memahami dan menilai kondisi suatu perusahaan, sehingga dapat lebih teliti dalam menemukan salah saji dan praktik kecurangan yang dilakukan oleh manajemen. Hal ini menunjukkan pangsa pasar auditor yang besar (KAP spesialis) mampu menghasilkan hasil audit yang berkualitas (Udayanti \& Ariyanto, 2017; Alareeni, 2019).

H3: Pangsa Pasar Auditor berpengaruh postif terhadap kualitas audit

\subsection{Faktor Auditee dan kualitas Audit}

Perusahaan yang besar cenderung memiliki keuangan yang lebih stabil serta pengawasan dan sistem pengendalian internal yang lebih efektif dibandingkan dengan perusahaan kecil (Nugrahanti \& Darsono, 2014). Hal tersebut dapat meminimalisasi praktik manajemen laba dan menyediakan informasi keuangan yang dapat diandalkan. Selain itu, perusahaan berukuran besar cenderung akan memilih auditor yang berkualitas. Pernyataan tersebut sejalan dengan hasil penelitian Berikang et al. (2018) dan Gacar (2016) yang menyatakan ukuran perusahaan klien berpengaruh positif terhadap kualitas audit.

H4: Ukuran perusahaan berpengaruh positif terhadap kualitas audit

Umur publikasi merupakan lamanya sebuah perusahaan terdaftar di Bursa Efek Indonesia. Semakin lama umur publikasi sebuah perusahan, mengindikasikan manajemen yang berkualitas dalam mengelola keuangan serta memiliki kemampuan dalam membayar premi yang tinggi untuk menyewa jasa auditor independen yang berkualitas, sebaliknya dengan perusahaan yang memiliki umur perusahaan yang singkat. Oleh karena itu, umur publikasi yang lama dapat memberikan pengaruh positif pada kualitas audit (Diana MD \& Majidah, 2019; Gacar, 2016). 


\section{H5: Umur Publikasi berpengaruh positif terhadap kualitas audit}

\section{Metode, Data dan Analisis}

Penelitian ini merupakan penelitian deskritif verifikatif yang bersifat kausalitas, sehingga perlu adanya pengujian hipotesis. Agar variable-variabel penelitian dapat dianalisis dan diuji hipotesis, maka perlu disusun definisi operasional dan pengukuran variabel sebagaimana tabel. 2 berikut ini:

\begin{tabular}{|c|c|c|c|}
\hline $\begin{array}{c}\text { Variab } \\
\text { el }\end{array}$ & Definisi & Indikator & Skala \\
\hline \multicolumn{4}{|c|}{ Variabel Dependen } \\
\hline $\begin{array}{c}\text { Kualitas } \\
\text { audit } \\
\text { (Y) }\end{array}$ & $\begin{array}{l}\text { Probabilit } \\
\text { as dan } \\
\text { kemam- } \\
\text { puan } \\
\text { auditor } \\
\text { dalam } \\
\text { mendetek } \\
\text { si salah } \\
\text { saji } \\
\text { material } \\
\text { dan } \\
\text { manipulas } \\
\text { i laba } \\
\text { bersih } \\
\text { pada } \\
\text { sistem } \\
\text { akuntansi } \\
\text { kliennya } \\
\text { serta } \\
\text { melapork } \\
\text { an temuan } \\
\text { pelanggar } \\
\text { an } \\
\text { tersebut } \\
\text { (Davidson } \\
\& \quad \text { Neu, } \\
\text { 1993; } \\
\text { dalam } \\
\text { Abdul- } \\
\text { Rahman } \\
\text { et al., } \\
\text { 2017; } \\
\text { DeAngelo } \\
\text {, 1981). }\end{array}$ & 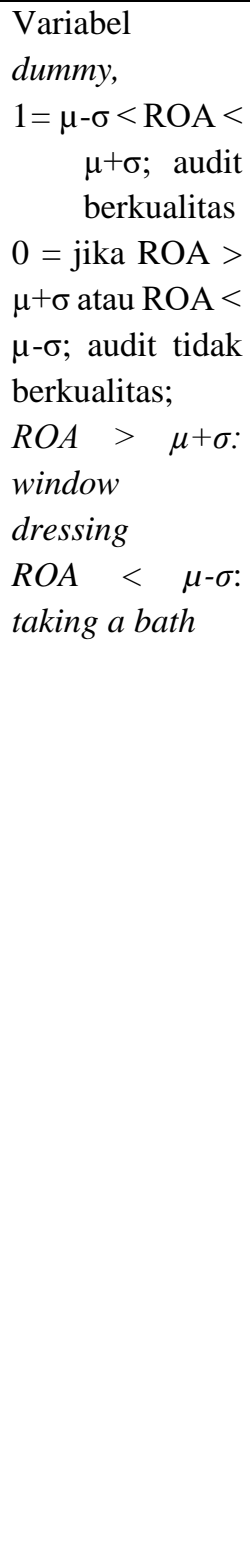 & $\begin{array}{c}\text { Nomin } \\
\text { al }\end{array}$ \\
\hline
\end{tabular}

\begin{tabular}{|c|c|c|c|}
\hline $\begin{array}{c}\text { Audit } \\
\text { tenure } \\
\left(\mathrm{X}_{1}\right)\end{array}$ & $\begin{array}{l}\text { Periode } \\
\text { persetujan } \\
\text { perikatan } \\
\text { audit atau } \\
\text { lamanya } \\
\text { seorang } \\
\text { auditor } \\
\text { mengaudi } \\
\text { t } \\
\text { perusahaa } \\
\text { n klien } \\
\text { dalam } \\
\text { suatu } \\
\text { perikatan } \\
\text { serta } \\
\text { jangka } \\
\text { waktu } \\
\text { kerja } \\
\text { sama } \\
\text { antara } \\
\text { KAP } \\
\text { dengan } \\
\text { auditee } \\
\text { yang } \\
\text { sama } \\
\text { (Hartadi, } \\
\text { 2009; } \\
\text { dalam } \\
\text { Abdul- } \\
\text { Rahman } \\
\text { et al., } \\
\text { 2017; } \\
\text { Yolanda } \\
\text { et } \\
\text { 2019). }\end{array}$ & $\begin{array}{lr}\text { Nilai } & \text { absolut } \\
\text { dari } & \text { jumlah } \\
\text { tahun } & \text { perikatan } \\
\text { auditor } & \text { dengan } \\
\text { auditee } & \end{array}$ & Rasio \\
\hline $\begin{array}{c}\text { Audit } \\
\text { fee } \\
\left(\mathrm{X}_{2}\right)\end{array}$ & $\begin{array}{l}\text { Jumlah } \\
\text { yang } \\
\text { dibebanka } \\
\mathrm{n} \quad \text { oleh } \\
\text { auditor } \\
\text { untuk } \\
\text { penugasa } \\
\mathrm{n} \quad \text { audit } \\
\text { yang } \\
\text { dilakukan } \\
\text { untuk } \\
\text { setiap } \\
\text { pekerjaan } \\
\text { yang } \\
\text { dilaku- } \\
\text { kannya }\end{array}$ & $\begin{array}{l}F E E \quad=\quad \text { Ln } \\
(\text { Auditfee }) \\
\text { atau } \\
F E E=\text { Ln }(10 \% \\
\text { professional } \\
\text { fee) }\end{array}$ & Rasio \\
\hline
\end{tabular}

https://journals.telkomuniversity.ac.id/jaf E-ISSN 2581-1088 


\begin{tabular}{|c|c|c|c|}
\hline & $\begin{array}{l}\text { dalam } \\
\text { mengung- } \\
\text { kapkan } \\
\text { pendapat } \\
\text { tentang } \\
\text { keadaan } \\
\text { yang } \\
\text { benar dan } \\
\text { adil dari } \\
\text { perusahaa } \\
\text { n klien } \\
\text { (Abdul- } \\
\text { Rahman } \\
\text { et al., } \\
\text { 2017). }\end{array}$ & & \\
\hline $\begin{array}{c}\text { Pangsa } \\
\text { pasar } \\
\text { auditor } \\
\left(\mathrm{X}_{3}\right)\end{array}$ & $\begin{array}{l}\text { Seberapa } \\
\text { besar } \\
\text { KAP } \\
\text { dapat } \\
\text { menguasa } \\
\text { i pasar } \\
\text { pada } \\
\text { suatu } \\
\text { kelompok } \\
\text { perusahaa } \\
\text { n ataupun } \\
\text { industri. } \\
\text { (Mulyono } \\
\& \\
\text { Majidah, } \\
\text { 2015; } \\
\text { Karman, } \\
\text { Abdi, \& } \\
\text { Ardina, } \\
\text { 2017). }\end{array}$ & $\begin{array}{l}\text { PPA } \\
=\frac{\text { Jumlah klien }}{\text { Jumlah sampel }} \\
\times \frac{\text { Rerat aset klien }}{\text { Rerata aset sampe }} \\
\text { Variabel } \\
\text { dummy, } \\
1=\text { persentase } \\
\text { hasil > rata-rata } \\
\text { persentase } \\
\text { keseluruhan } \\
\text { data; auditor } \\
\text { pangsa pasar } \\
0 \quad=\quad \text { jika } \\
\text { persentase hasil } \\
\leq \quad \text { rata-rata } \\
\text { persentase } \\
\text { keseluruhan } \\
\text { data; bukan } \\
\text { auditor pangsa } \\
\text { pasar }\end{array}$ & $\begin{array}{l}\text { Nomin } \\
\text { al }\end{array}$ \\
\hline $\begin{array}{c}\text { Ukuran } \\
\text { Perusah } \\
\text { a-an } \\
\left(\mathrm{X}_{4}\right)\end{array}$ & $\begin{array}{l}\text { Perusahaa } \\
\mathrm{n} \quad \text { yang } \\
\text { besar } \\
\text { cenderung } \\
\text { memiliki } \\
\text { keuangan } \\
\text { yang lebih } \\
\text { stabil } \\
\text { serta } \\
\text { pengawas } \\
\text { an dan } \\
\text { sistem } \\
\text { pengen- } \\
\text { dalian } \\
\text { internal }\end{array}$ & $\begin{array}{l}\text { SIZE = Ln (Total } \\
\text { pitalisasi pasar) }\end{array}$ & Rasio \\
\hline
\end{tabular}

\begin{tabular}{|c|c|c|c|}
\hline & $\begin{array}{l}\text { yang lebih } \\
\text { efektif } \\
\text { dibanding } \\
\text {-kan } \\
\text { dengan } \\
\text { perusahaa } \\
\text { n kecil } \\
\text { (Nugraha } \\
\text { nti \& } \\
\text { Darsono, } \\
\text { 2014). }\end{array}$ & & \\
\hline $\begin{array}{c}\text { Umur } \\
\text { publika } \\
\text { si } \\
\left(\mathrm{X}_{5}\right)\end{array}$ & $\begin{array}{l}\text { Jangka } \\
\text { waktu } \\
\text { perusahaa } \\
\text { n listing di } \\
\text { Bursa } \\
\text { Efek } \\
\text { Indonesia. }\end{array}$ & $\begin{array}{l}A G E \\
=\text { Tahun penelitial } \\
\text { - tahun listing }\end{array}$ & Rasio \\
\hline
\end{tabular}

Objek penelitian adalah BUMN nonkeuangan yang listing di Bursa Efek Indonesia tahun 2014-2018. Penelitian ini menggunakan data sampel dengan teknik sampling purposive sampling, dengan kriteria sampling (Sugiyono, 2018:85); (1) Perusahaan BUMN non-keuangan yang secara konsisten listing di Bursa Efek Indonesia selama tahun 2014-2018. Dan (2) Perusahaan BUMN non-keuangan yang secara konsisten mempublikasikan laporan tahunan dan laporan keuangan auditan selama tahun 20142018. Dan diperoleh 16 BUMN non-keuangan atau 80 data observasi.

Analisis statistik yang digunakan adalah analisis regresi logistik, karena variabel dependen berskala nominal. Persamaan regresi logistik sebagai berikut:

$$
\begin{gathered}
\operatorname{Ln} \frac{\mathrm{KA}}{1-\mathrm{KA}}=\alpha+\beta_{1} T E N+\beta_{2} F E E+\beta_{3} P P A+\beta_{4} S I Z E \\
+\beta_{5} A G E+\varepsilon
\end{gathered}
$$

Di mana:

KA : Kualitas Audit (earning surprise benchmark, $1=$ audit berualitas, $0=$ audit tidak berkualitas)

$\alpha \quad$ : Konstanta

$\beta_{n} \quad$ : Koefisien regresi dari setiap variabel independen

TEN : Audit Tenure (jumlah tahun perikatan audit)

FEE : Audit Fee (Ln Audit fee atau Ln 10\% professional fee)

PPA : Pangsa Pasar Auditor (1= auditor pangsa pasar, $0=$ bukan auditor pangsa pasar)

SIZE : Ukuran Perusahaan (Ln total kapitalisasi pasar) 


$\begin{array}{lll}A G E & : \quad \text { Umur Publikasi } & \text { (tahun penelitian - } \\ & \text { tahun listing) } \\ \varepsilon & : \text { Standard Error }\end{array}$

\section{Hasil dan Diskusi}

Hasil analisis regresi logistik dan pengujian hipotesis dengan software IBM SPSS 25 sebagai berikut:

Menilai kelayakan Model Regresi sebagaimana tabel.3, menggunakan tes Hosmer dan Lemeshow, dengan hasil sebagai berikut:

\section{Tabel 3. Pengujian Kelayakan Model Regresi}

\begin{tabular}{|l|r|r|r|}
\hline \multicolumn{5}{|c|}{ Hosmer and Lemeshow Test } \\
\hline Step & Chi-square & df & Sig. \\
\hline 1 & 7,304 & 8 &, 504 \\
\hline \multicolumn{4}{|c|}{ Sumber: Output SPSS 25} \\
\hline
\end{tabular}

Tabel 3. menunjukkan nilai chi-square sebesar 7,304 dengan nilai probabilitas signifikansinya sebesar 0,504 yang lebih besar dari $0,05(\alpha=5 \%)$. Hipotesis nol $\left(\mathrm{H}_{0}\right)$ diterima yang berarti model regresi mampu memprediksi nilai observasi atau model telah cocok dengan data observasi.

Menilai model fit juga perlu dilakukan, yaitu menilai kecocokan keseluruhan model (overall model fit) dengan membandingkan nilai -2Log likelihood pada langkah awal (block 0) dan langkah berikutnya (block 1) setelah dimasukkan variabel independen ke dalam model. Berikut perbandingan kedua nilai:

\section{Tabel 4 Overall Model Fit}

\begin{tabular}{|c|c|}
\hline Block Number & -2Log Likelihood \\
\hline 0 & 92,189 \\
\hline 1 & 63,755 \\
\hline
\end{tabular}

Sumber: Output SPSS 25

Tabel 4. menunjukkan nilai -2 LogL sebesar 92,189 dari langkah awal (block 0) yang hanya memasukkan konstanta pada model, kemudian -2LogL turun menjadi 63,755 pada langkah selanjutnya (block 1). Penurunan tersebut dapat diartikan bahwa variabel independen berupa audit tenure, audit fee, pangsa pasar auditor, ukuran perusahaan, dan umur publikasi yang ditambahkan ke dalam model dapat memperbaiki model fit. Dengan kata lain, hipotesis nol $\left(\mathrm{H}_{0}\right)$ diterima, model yang dihipotesiskan telah fit dengan data.

Tahapan setelah model diyatakan layak dan fit, maka hasil analisis dan pengujian hipotesis adalah sebagai berikut:

\subsection{Koefisien Diterminasi dan Pengujian Simultan}

Koefisien determinasi dapat dilihat dari nilai Nagelkerke $R$ Square pada hasil pengujian regresi logistik. Pada awal pengujian hasil analisis tidak menunjukkan hasil yang diharapkan, kemudian dilakukan deteksi terhadap pecilan data (outlier) yang mengganggu. Dijumpai 3 data outlier, sehingga dikeluarkan dari analisis data, kemudian dianalisis dan pengujian hipotesis ulang. Berikut tabel hasil pengujian:

Tabel 5. Koefisien Determinasi

\begin{tabular}{|l|c|c|c|}
\hline \multicolumn{4}{|c|}{ Model Summary } \\
\hline Step & $\begin{array}{c}-2 \text { Log } \\
\text { likelihood }\end{array}$ & $\begin{array}{c}\text { Cox \& Snell R } \\
\text { Square }\end{array}$ & $\begin{array}{c}\text { Nagelkerke R } \\
\text { Square }\end{array}$ \\
\hline 1 & $63,755^{\mathrm{a}}$ &, 308 &, 442 \\
\hline
\end{tabular}

a. Estimation terminated at iteration number 6 because parameter estimates changed by less than ,001.

\section{Sumber: Output SPSS 25}

Tabel 5. munjukkan nilai dari Nagelkerke $R$ Square adalah sebesar 0,442. Nilai tersebut menjelaskan variabilitas dari variabel dependen dapat dijelaskan oleh variabilitas variabel independen sebesar 44,2\%. Sedangkan sisanya dijelaskan oleh variabel independen lain di luar penelitian.

Pengujian simultan pada regresi logistik dilakukan dengan omnibus test untuk mengetahui pengaruh dari audit tenure, audit fee, pangsa pasar auditor, ukuran perusahaan, dan umur publikasi secara simultan berpengaruh terhadap kualitas audit. Tabel 6. Berikut merupakan hasil pengujian simultan: 
Tabel 6. Pengujian Simultan

\begin{tabular}{|l|l|r|r|c|}
\hline \multicolumn{5}{|c|}{ Omnibus Tests of Model Coefficients } \\
\hline \multirow{2}{|c|}{} & Chi-square & df & Sig. \\
\hline Step 1 & Step & 28,378 & 5 &, 000 \\
\cline { 2 - 5 } & Block & 28,378 & 5 &, 000 \\
\cline { 2 - 5 } & Model & 28,378 & 5 &, 000 \\
\hline
\end{tabular}

Sumber: Output SPSS 25

Tabel 6. menunjukkan nilai chi-square sebesar 28,378 dengan tingkat signifikansi sebesar $0,000<0,05 \quad(\alpha=5 \%)$. Dengan demikian, $\mathrm{H}_{1}$ diterima yang berarti audit tenure, audit fee, pangsa pasar auditor, ukuran perusahaan, dan umur publikasi berpengaruh secara simultan terhadap kualitas audit.

\subsection{Pengujian Parsial}

Pengujian parsial dalam penleitian ini digunakan untuk mengetahui pengaruh dari masing-masing variabel independen terhadap variabel dependen. Berikut hasil pengujian parsial:

\section{Tabel 7. Pengujian Parsial}

\begin{tabular}{|c|c|c|c|c|c|c|c|}
\hline \multicolumn{8}{|c|}{ Variables in the Equation } \\
\hline & & B & S.E. & $\begin{array}{c}\text { Wa } \\
\text { ld }\end{array}$ & $\begin{array}{l}d \\
f\end{array}$ & $\begin{array}{l}\mathrm{Si} \\
\mathrm{g} .\end{array}$ & $\operatorname{Exp}(B)$ \\
\hline \multirow{7}{*}{$\begin{array}{l}\text { St } \\
\text { ep } \\
1 \mathrm{a}\end{array}$} & Audit & - & ,526 & 6,8 & 1 & , 0 & ,253 \\
\hline & Tenure & $\begin{array}{r}1,37 \\
3\end{array}$ & & 01 & & 09 & \\
\hline & $\begin{array}{l}\text { Audit } \\
\text { Fee }\end{array}$ & , & ,419 & $\begin{array}{r}1,4 \\
19\end{array}$ & 1 & $\begin{array}{r}, 2 \\
34\end{array}$ & ,607 \\
\hline & $\begin{array}{l}\text { Pangsa } \\
\text { Pasar } \\
\text { Auditor( } \\
\text { 1) }\end{array}$ & $\begin{array}{r}2,21 \\
9\end{array}$ & ,958 & $\begin{array}{r}5,3 \\
70\end{array}$ & 1 & $\begin{array}{l}, 0 \\
20\end{array}$ & , 109 \\
\hline & $\begin{array}{l}\text { Ukuran } \\
\text { Perusah } \\
\text { aan }\end{array}$ & ,333 & ,319 & $\begin{array}{r}1,0 \\
90\end{array}$ & 1 & $\begin{array}{r}, 2 \\
97\end{array}$ & ,717 \\
\hline & $\begin{array}{l}\text { Umur } \\
\text { Publika } \\
\text { si }\end{array}$ & ,001 & ,056 & $\begin{array}{r}, 00 \\
0\end{array}$ & 1 & $\begin{array}{r}9 \\
90\end{array}$ & 1,001 \\
\hline & $\begin{array}{l}\text { Constan } \\
\text { t }\end{array}$ & $\begin{array}{r}25,1 \\
14\end{array}$ & $\begin{array}{r}11,3 \\
38\end{array}$ & \begin{tabular}{r|}
4,9 \\
06
\end{tabular} & 1 & $\begin{array}{r}0 \\
27\end{array}$ & $\begin{array}{r}8070711531 \\
9,838 \\
\end{array}$ \\
\hline \multicolumn{8}{|c|}{$\begin{array}{l}\text { a. Variable(s) entered on step 1: Audit Tenure, } \\
\text { Audit Fee, Pangsa Pasar Auditor, Ukuran } \\
\text { Perusahaan, Umur Publikasi. }\end{array}$} \\
\hline
\end{tabular}

Sumber: Output SPSS 25

Model persamaan regresi logistik sebagaimana Tabel.7 sebagai berikut:
$\operatorname{Ln} \frac{\mathrm{KA}}{1-\mathrm{KA}}=25,114-1,373$ TEN $-0,499 \mathrm{FEE}-$ 2,219PPA - 0,333SIZE + 0,001AGE

Persamaan model regresi logistik, diinterpretasikan sebagai berikut:

1) Nilai konstanta diperoleh sebesar 25,114 dengan tingkat signifikansi $0,027<0,05$ $(\alpha=5 \%)$. Hasil tersebut menunjukkan bahwa jika variabel independen yang terdiri dari audit tenure, audit fee, pangsa pasar auditor, ukuran perusahaan, dan umur publikasi sama dengan nol atau konstan, maka hasil audit tetap berkualitas.

2) Nilai koefisien audit tenure sebesar -1,373 dengan tingkat signifikansi $0,009<0,05$ $(\alpha=5 \%)$. Hasil tersebut menunjukkan bahwa audit tenure berpengaruh negatif terhadap kualitas audit.

3) Nilai koefisien audit fee sebesar -0,499 dengan tingkat signifikansi $0,234>0,05$ $(\alpha=5 \%)$. Hasil tersebut menunjukkan bahwa audit fee tidak berpengaruh terhadap kualitas audit.

4) Nilai koefisien pangsa pasar auditor sebesar -2,219 dengan tingkat signifikansi $0,020<0,05 \quad(\alpha=5 \%)$. Hasil tersebut menunjukkan bahwa pangsa pasar auditor berpengaruh negatif terhadap kualitas audit.

5) Nilai koefisien ukuran perusahaan sebesar $-0,333$ dengan tingkat signifikansi $0,297>$ $0,05(\alpha=5 \%)$. Hasil tersebut menunjukkan bahwa ukuran perusahaan tidak berpengaruh terhadap kualitas audit.

6) Nilai koefisien umur publikasi sebesar 0,001 dengan tingkat signifikansi $0,990>$ $0,05(\alpha=5 \%)$. Hasil tersebut menunjukkan bahwa umur publikasi tidak berpengaruh terhadap kualitas audit.

\subsection{Diskusi}

Hasil penelitian dapat didiskusikan sebagai berikut: 


\section{Pengaruh Audit Tenure Terhadap Kualitas Audit}

Hasil pengujian parsial menunjukkan bahwa audit tenure berpengaruh negatif terhadap kualitas audit pada perusahaan. Hasil penelitian ini sejalan dengan hipotesis penelitian dan mendukung hasil penelitian Pramaswaradana \& Astika (2017) yang mengatakan bahwa masa perikatan yang lama antara auditor dan auditee dapat menurunkan kualitas audit. Walaupun audit tenure yang lama akan membuat auditor lebih memahami ruang lingkup perusahaan, namun hal tersebut justru dapat mengganggu independensi auditor, sehingga objektivitas untuk mendeteksi adanya window dressing dan taking a bath menjadi berkurang. Dengan kata lain, audit tenure yang pendek dapat menghasilkan audit yang berkualitas, sehingga berpotensi mengurangi konflik keagenan pada perusahaan.

\section{Pengaruh Audit Fee terhadap Kualitas Audit}

Audit fee tidak berpengaruh terhadap kualitas audit. Hasil penelitian tidak sesuai dengan hipotesis penelitian, dengan demikian tidak sejalan dengan hasil penelitian Abdul-Rahman et al. (2017), yang menyatakan bahwa audit fee berpengaruh positif terhadap kualitas audit.

Pada dasarnya, audit fee sendiri dipertimbangkan berdasarkan jenis jasa, kompleksitas pekerjaan, jumlah waktu dan personel dalam menyelesaikan proses audit (IAPI, 2016). Dengan demikian, Kualitas audit tidak ditentukan oleh besar kecilnya audit fee yang diterima auditor, tetapi ditentukan oleh profesionalisme dan kepatuhan terhadap kode etik profesi akuntan publik.

\section{Pengaruh Pangsa Pasar Auditor terhadap Kualitas Audit}

Pangsa pasar auditor berpengaruh negatif terhadap kualitas audit. Hasil ini bertolak belakang dengan hipotesis penelitian yang menyatakan bahwa pangsa pasar auditor berpengaruh positif terhadap kualitas audit. Dengan demikian, penelitian ini tidak sejalan dengan hasil penelitian Udayanti \& Ariyanto (2017) yang menyatakan bahwa KAP spesialis dapat mengurangi praktik manajemen laba, sehingga menghasilkan audit yang berkualitas. Istilah pangsa pasar auditor pada penelitian ini, merujuk kepada spesialisasi industri auditor, karena objek penelitian yang diteliti merupakan perusahaan BUMN non-keuangan yang terdiri atas berbagai industri.

Hubungan ini menunjukkan bahwa pangsa pasar auditor memiliki pengaruh negatif terhadap kualitas audit. Auditor yang menguasai pangsa pasar diindikasikan oleh banyaknya perikatan audit yang dilakukan oleh auditor tersebut. Hal ini mengakibatkan beban kerja auditor berlebih, sehingga berdampak pada perilaku disfungsional auditor yang terdiri atas perilaku pengurangan kualitas audit, pelaporan waktu audit yang tidak sesuai, dan pengurangan prosedur audit (Majidah, Isynuwardhana, \& Anna, 2016). Oleh karena itu, memungkinkan bagi auditor pangsa pasar mengalami perilaku disfungsional auditor untuk memenuhi tuntutan pangsa pasarnya, yang berdampak pada hasil audit yang tidak berkualitas.

\section{Pengaruh Ukuran Perusahaan terhadap Kualitas Audit}

Hasil penelitian menunjukkan bahwa ukuran perusahaan tidak berpengaruh terhadap kualitas audit. Hasil penelitian tidak mendukung hipotesis penelitian yang menyatakan bahwa ukuran perusahaan berpengaruh positif terhadap kualitas audit. Penelitian ini tidak sejalan dengan hasil penelitian Berikang et al. (2018) yang menjelaskan bahwa semakin besar ukuran perusahaan, maka kualitas audit yang dihasilkan akan menjadi lebih tinggi.

Penyebab ukuran perusahaan tidak mempengaruhi kualitas audit, karena variabel ukuran perusahaan diproksikan dengan kapitalisasi pasar yang merupakan faktor eksternal dari pendanaan perusahaan, yang bukan menjadi objek utama dalam audit laporan 
keuangan, sehingga ukuran perusahaan cenderung tidak stabil karena bergantung kepada investor. Oleh karena itu dalam hasil penelitian ini, ukuran perusahaan bukan faktor determinan kualitas audit.

\section{Pengaruh Umur Publikasi terhadap Kualitas Audit}

Umur publikasi tidak berpengaruh terhadap kualitas audit pada perusahaan BUMN non-keuangan yang terdaftar di Bursa Efek Indonesia. Dengan demikian, hasil tersebut tidak mendukung hipotesis yang menyatakan bahwa umur publikasi berpengaruh positif terhadap kualitas audit. Hasil penelitian ini juga tidak sejalan dengan hasil penelitian Diana MD \& Majidah (2019) yang mengungkapkan bahwa perusahaan yang berumur lebih panjang memiliki pengalaman yang lebih banyak, sehingga dapat membantu auditor menghasilkan audit yang berkualitas.

Hasil isi menunjukkan bahwa perusahaan BUMN non-keuangan yang lama ataupun yang baru listing di Bursa Efek Indonesia, harus tetap diaudit oleh auditor yang berkualitas, sehingga umur publikasi bukan merupakan faktor determinan dari kualitas audit.

\section{Kesimpulan, Keterbatasan dan Saran}

\subsection{Kesimpulan}

Berdasarkan hasil penelitian dan diskusi, dapat disimpulkan bahwa secara parsial yang mempengaruhi kualitas audit hanyalah faktor auditor, yaitu audit tenure dan pangsa pasar auditor. Dimana audit tenure berpengaruh positif, sedangkan pangsa pasar auditor berpengaruh negative.

\subsection{Keterbatasan Penelitian}

Variabel penelitian yang mempengaruhi kualitas audit hanya dua yaitu audit tenure dan pangsa pasar auditor, ketiga variabel lainnya bukan faktor determinan kualitas audit di BUMN. Khususnya kapitalisasi pasar sebagai proksi ukuran perusahaan, bukan faktor internal yang menjadi objek audit secara langsung yang juga dapat menunjukkan kompleksitas perusahaan yang dapat menentukan kualitas audit.

\subsection{Saran}

Mengacu pada hasil Penelitian dan pembahasan, disarankan kepada peneliti selanjutnya. Untuk menguji kembali terhadap variabel-variabel yang tidak mendukung hipotesis penelitian pada objek penelitian serta periode pengamatan yang berbeda dan dapat mengganti proksi ukuran perusahaan selain kapitalisasi pasar auditor. Sementara itu, bagi auditor, disarankan untuk mempertimbangkan beban kerja auditor, karena dikhawatirkan menimbulkan perilaku disfungsional auditor yang dapat menghasilkan audit tidak berkualitas.

\section{Daftar Pustaka}

Abdul-Rahman, D. A., Benjamin, A. O., \& Olayinka, O. H. (2017). Effect of Audit Fees on Audit Quality: Evidence from Cement Manufacturing Companies in Nigeria. European Journal of Accounting, Auditing and Finance Research, 1(5), 617.

Alareeni, B. A. (2019). The Associations Between Audit Firm Attributes and Audit Quality-Specific Indicators. Managerial Auditing Journal, Vol. 34, No.1, 6-34.

Alfariza, B. K., Majidah, \& Nurbaiti, A. (2017). Analisis Determinan Kualitas Audit (Studi pada Perusahaan yang Terdaftar di Indeks Kompas100 Periode 2012-2016). e-Proceeding of Management, 3(4), 25702574.

Berikang, A., Kalangi, L., \& Wokas, H. (2018). Pengaruh Ukuran Perusahaan Klien dan Rotasi Audit terhadap Kualitas Audit pada Perusahaan Manufaktur yang Terdaftar di BEI Tahun 2012-2015. Jurnal Riset Akuntansi Going Concern, 1-9.

DeAngelo, L. E. (1981). Auditor Size and Audit Quality. Journal of Accounting and Economics, 183-199.

Diana MD, D., \& Majidah. (2019). Kualitas 
Audit: Audit Tenure, Beban Kerja Auditor, Alignment dan Entrenchment Effect. Jurnal Ilmiah MEA (Manajemen, Ekonomi, \& Akuntansi), 3(2),5-13.

Gacar, A. (2016). Relationship Between Audit Quality and Corporate Governance: An Empirical Research in Borsa Istanbul. IOSR Journal of Business and Management, Vol. 16, 84-88.

IAPI. (2012). Standar Audit ("SA") 500 Bukti Audit. Jakarta: IAPI.

IAPI. (2016). Peraturan Pengurus Nomor 2 Tahun 2016 tentang Penentuan Jasa Audit Laporan Keuangan. Jakarta: IAPI.

IAPI. (2018). Keputusan Dewan Pengurus Institut Akuntan Publik Indonesia Nomor 4 Tahun 2018 tentang Panduan Indikator Kualitas Audit pada Kantor Akuntan Publik. Jakarta: IAPI.

Jensen, M., \& Meckling, W. (1976). Theory of The Firm: Managerial Behavior, Agency Cost and Ownership C. Journal of Financials Economics, 3, 305-360.

Karman, I., Abdi, I., \& Ardina, C. (2017). Pengaruh Jenis, Spesialisasi Industri Auditor, Audittenure, Ukuran Perusahaan terhadap Going Concern Reporting. Journal of Applied Accounting and Taxation Vol.2 No.2, $2,134-142$.

Majidah, Isynuwardhana, D., \& Anna, Y. D. (2016). Audit Quality: Time Budget Pressure, Dysfunctional Auditor Behavior and Understanding of Information Technology as Moderator. The 7th Smart Business in Technology and Information Industry.

Mulyono, A., \& Majidah. (2015). Auditor Switching: Perbedaan Aktivitas dan Pangsa Pasar Auditor setelah Corporate Takeovers. e-Proceeding of Management: Vol.2 No.2, 17141721
Ndubuisi, A. N., \& Ezechukwu, B. (2017). Determinants of Audit Quality: Evidence from Deposit Money Banks Listed on Nigeria Stock Exchange. International Journal of Academic Research in Accounting, Finance, and Management Science, 2(7), 117-130.

Nugrahanti, Y., \& Darsono. (2014). Pengaruh Audit Tenure, Spesialisasi Kantor Akuntan Publik, dan Ukuran Perusahaan terhadap Kualitas Audit. Diponegoro Journal of Accounting, 3(3), 4-8.

Paramita, N. A., \& Latrini, N. Y. (2015). Pengaruh Ukuran Perusahaan, Umur Publikasi, Masa Perikatan Audit, Pergantian Manajemen pada Kualitas Audit. E-Jurnal Akuntansi Universitas Udayana, 142-156.

Pemerintah RI. (2015). Peraturan Pemerintah Republik Indonesia Nomor 20 tahun 2015 tentang Praktik Akuntan Publik. Jakarta.

Pham, N. K., Duong, H. N., \& Quang, T. P. (2017). Audit Firm Size, Audit Fee, Audit Reputation and Audit Quality: The Case of Listed Companies in Vietnam. Asian Journal of Finance \& Accounting, Vol. 1 No. 1, 429-447.

Pramaswaradana, I. N., \& Astika, I. P. (2017). Pengaruh Audit Tenure, Audit Fee, Rotasi Auditor, Spesialisasi Auditor, dan Umur Publikasi pada Kualitas Audit. E-Jurnal Akuntansi Universitas Udayana, 1(19), 189-191.

Pusparisa, Y. (2019). Polemik Laporan Keuangan Garuda Indonesia. Tersedia: https://katadata.co.id/infografik/2019/07/ 08/polemik-laporan-keuangan-garudaindonesia.

Sugiyono. (2018). Metode Penelitian Kuantitatif, Kualitatif, dan $R \& D$. Bandung: Alfabeta.

Udayanti, N. S., \& Ariyanto, D. (2017). Pengaruh Auditor Switching, Ukuran Perusahaan, Spesialisasi Industri KAP, dan Client Importance pada Kualitas Audit. E-Jurnal Akuntansi Universitas Udayana, 2(20), 1082-1097.

Yolanda, S., Arza, F. I., \& Halmawati. (2019). Pengaruh Audit Tenure, Komite Audit dan Audit Capacity Stress terhadap Kualitas 
Journal Accounting and Finance

Edisi Vol. 4 No. 2 September 2020

Universitas Telkom

Audit. Jurnal Eksplorasi Akuntansi,

Vol. 1 No. 2, 543-55 